\title{
MANUFACTURE OF SPECIMENS AND MECHANICAL PROPERTIES DETERMINATION OF STRUCTURAL ADHESIVES UNDER STATIC LOADING CONDITION
}

\author{
P. Maćkowiak* ${ }^{*}$ B. Ligaj**
}

\begin{abstract}
The paper presents the method of manufacturing specimens for testing mechanical properties of structural adhesives during a monotonic tensile test and the method of determining the Poisson ratio. Tests carried out on two examples of structural adhesives: Plexus MA300 and Epidian 53 cured with hardener Z1, differ significantly in viscosity in open time. This requires the use of other methods of manufacturing specimens with a low number of defects and high repeatability. Due to the exothermic crosslinking process, specimens for testing construction adhesives can not have large dimensions. Therefore, it is not possible testing with two extensometers to measure longitudinal and transverse deformations at the same time. The article presents the method of measuring deformations in two load cycles.
\end{abstract}

Keywords: Poisson ratio, construction adhesives, mechanical properties, manufacture of specimens

\section{Introduction}

Adhesives are a group of materials, classified as plastics, which are not widely researched in terms of mechanical properties, such as metal materials or construction plastics (Wirwicki et al., 2017). Manufacturers limit the testing of their products to: tensile strength, Young's modulus and elongation at break of adhesive, shear strength of a standard overlap joint (Maćkowiak and Ligaj, 2017b). Due to the crosslinking process and the high adhesiveness, it is important issue to make specimens, which would have no internal defects (da Silva et al., 2012, da Silva and Adams, 2005).

For many calculations, it is necessary to know Poisson's ratio (Soltysiak et al., 2016). Existing methods of its determination, discussed in the previous work of the authors (Maćkowiak and Ligaj, 2016). One of the methods is to calculate the ratio of transverse to longitudinal deformations in a tensile specimen. Due to the small size of the samples, it is not possible to mount both extensometers on the specimen at the same time. A test method has been proposed, consisting in measuring transverse deformations in the initial load cycle in the elastic range of material and longitudinal deformations in the cycle of the basic load until specimen breaks (Adams and Wake, 1984).

\section{Methods}

\subsection{Material and method of specimens preparation}

The material for testing was two-component structural adhesives for joining metals, plastics and ceramics: Plexus MA300 methacrylic adhesive and Epidian 53 epoxy adhesive cured with Z1 hardener. The specimens for determining static mechanical properties were designed in accordance with the PN-EN ISO 527-2-1998 standard, using the dimensioning for small 1BB shape (Fig. 1).

\footnotetext{
Mgr inż. Paweł Maćkowiak, Wydział Inżynierii Mechanicznej, Uniwersytet Technologiczno-Przyrodniczy w Bydgoszczy, al. Prof. S. Kaliskiego 7, 85-796 Bydgoszcz,PL, pawel.mackowiak@utp.edu.pl

** Dr hab. inż. Bogdan Ligaj Wydział Inżynierii Mechanicznej, Uniwersytet Technologiczno-Przyrodniczy w Bydgoszczy, al. Prof. S. Kaliskiego 7, 85-796 Bydgoszcz,PL, bogdan.ligaj@utp.edu.pl
} 
Specimen of methacrylic adhesive were made of cast plates with dimensions of $65 \mathrm{~mm} \times 35 \mathrm{~mm} \times 3 \mathrm{~mm}$, in the form shown in Figure 1b. A static mixer was used to mix the component of adhesive. The paste material was applied closer to one edge of the mold, and then the mold was closed at a slight angle to distribute the adhesive inside. This method of application reduces the risk of air bubbles in the casting. To avoid sticking the molded material to the mold, its interior consisted of Teflon plate and a silicone frame. Methacrylic adhesives are characterized by a short time to obtain initial strength. After one day, the mold was opened and the cast plate removed. Then, the target shape of the samples was milled from the plate (Maćkowiak et al., 2017a).

a)

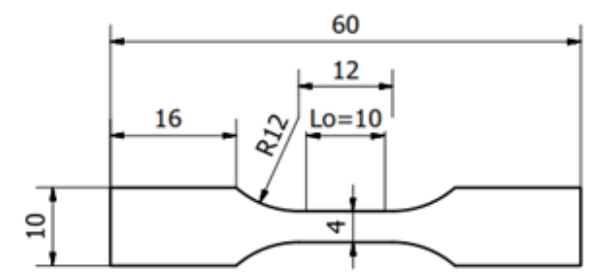

b)

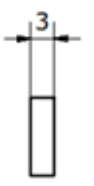

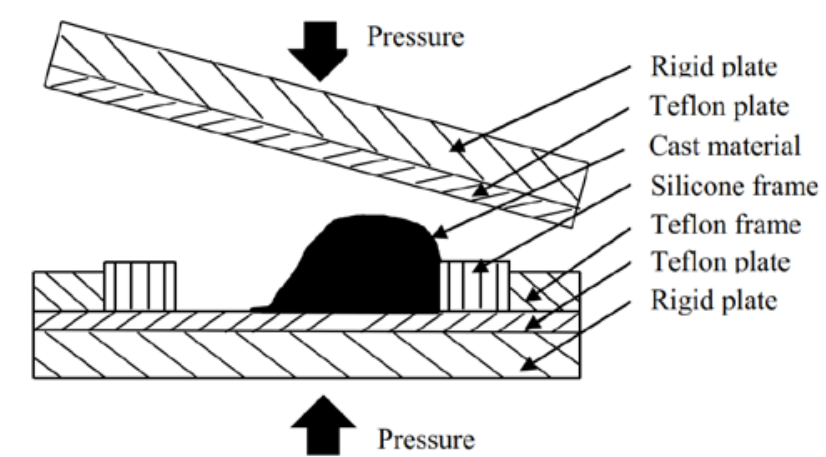

Fig. 1: a) Dimensions of the test specimens for mechanical properties under static tension based on PN-EN ISO 527-2-1998; b) Method of casting high viscosity adhesives.

Specimen of epoxy adhesive were also made of cast plates with dimensions of $65 \mathrm{~mm} \times 35 \mathrm{~mm} \times 3 \mathrm{~mm}$, but it was casted in open form. Epidian 53 epoxy adhesive is characterized by low viscosity and long time to obtain initial strength. Due to the fact, that its consistency is liquid, the venting of the casting takes place spontaneously under the influence of gravity. After a week, the cast plate was removed from the mold. Then, the target shape of the specimens was milled from the plate. The samples (Fig. 2) were seasoned for one month in room conditions $\left(20 \pm 2{ }^{\circ} \mathrm{C}\right.$, humidity $\left.45 \pm 5 \%\right)$ and then tested.

a)

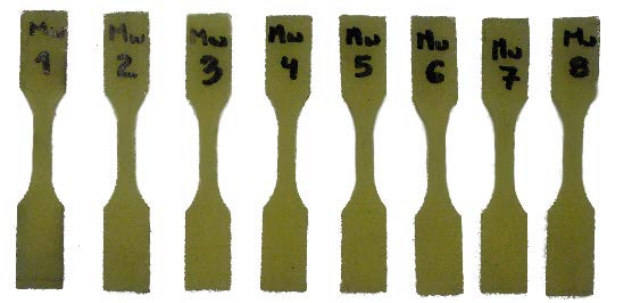

b)

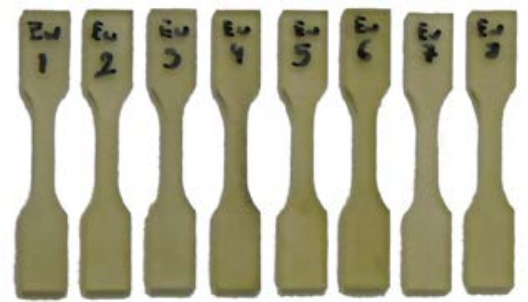

Fig. 2: Specimens of: a) methacrylic adhesive Plexus MA300; b) epoxy adhesive Epidian 53.

\subsection{Test method}

The specimens were fixed in the mechanical jaw holders of the INSTRON 5966 strength testing machine (Fig. 3a) with a force measuring device with a range of up to $10 \mathrm{kN}$. The tests were carried out in ambient conditions, ie $20 \pm 2^{\circ} \mathrm{C}$ and $45 \pm 5 \%$ humidity). During the tests the displacement parameter for a constant value was accepted in both directions to be equal to $0.005 \mathrm{~mm} / \mathrm{s}$. Two extensometers were used during the tests: extensometer for measuring longitudinal strain with $10 \mathrm{~mm}$ measurement base and a measuring range of $\pm 1 \mathrm{~mm}$ (Fig. 3b) and an extensometer for measuring transverse deformations with an adjustable measuring base and measuring range of $\pm 0.5 \mathrm{~mm}$ (Fig. 3c). The tests were carried out on 5 specimens of each material. Due to the small dimensions of the specimens, it is not possible to set both extensometers at the same time.

It proposed a method of measuring the transverse deformations in the preliminary cycle and then changes the extensometers and measuring the longitudinal strain in the second loading cycle. lasting to broken specimen. The load chart is shown in Figure 4a. The level of the maximum load in the first cycle was based on the load values determined in the preliminary tests, causing the longitudinal deformation of the sample by more than $0.0025 \mathrm{~mm} / \mathrm{mm}$ but much less than the yielding plasticity. This is due to the normative range of relative deformations from 0.0005 to $0.0025 \mathrm{~mm} / \mathrm{mm}$ taken into account when determining the Young's modulus for plastics. 
a)

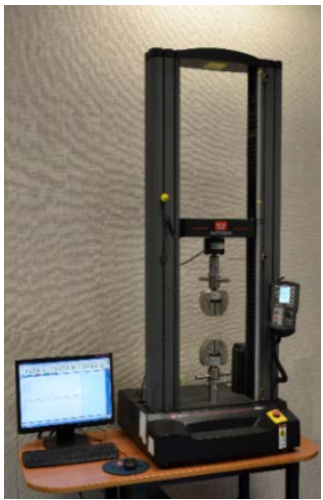

b)

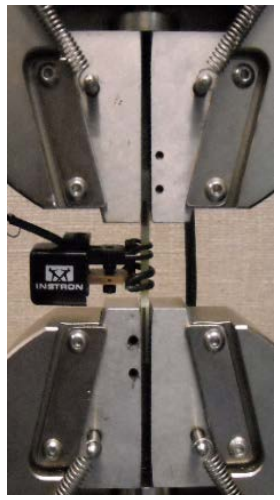

c)

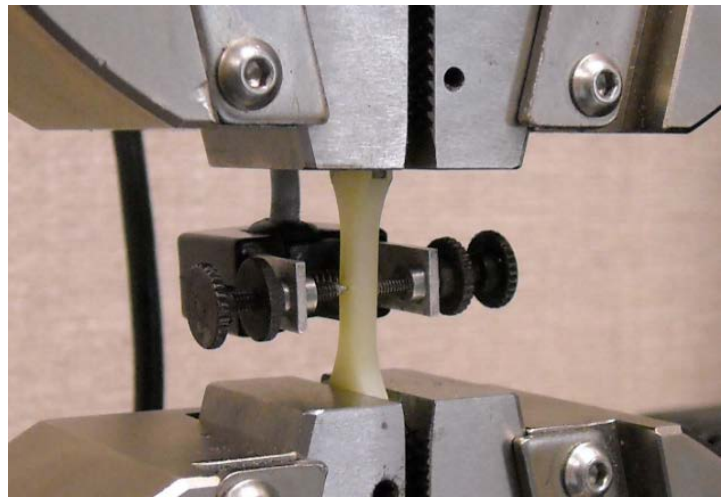

Fig. 3: a) INSTRON 5966 testing machine; b) Dumb type test piece in end machine holders with a longitudinal extensometer mounted; c) Transverse extensometer mounted.

a)

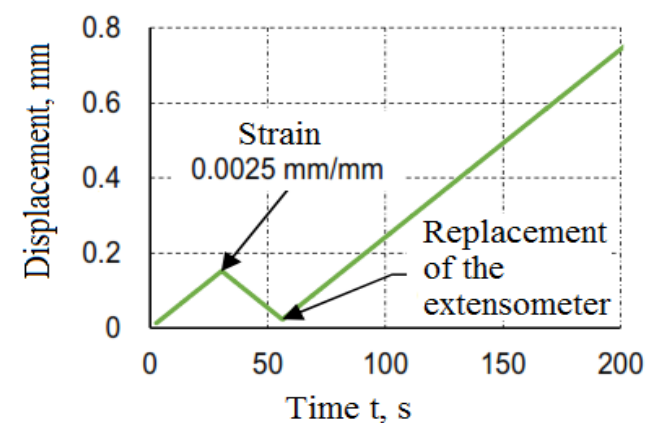

b)

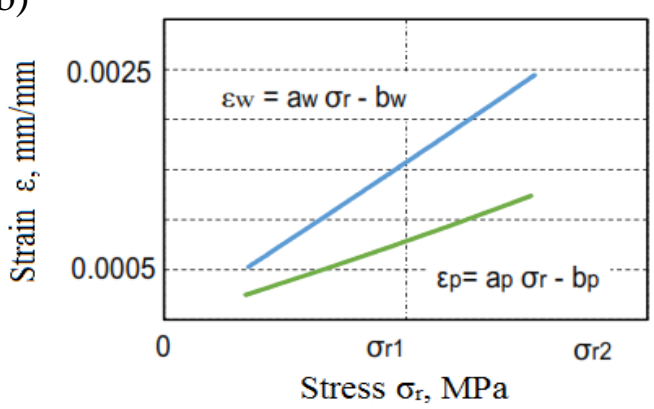

Fig. 4: a) The course of the test in time function; b) Longitudinal and transverse strain diagram in stress function.

Poisson's ratio $v$ was calculated by transforming the dependence:

$$
v=-\frac{\varepsilon_{p}}{\varepsilon_{w}}
$$

Due to the separate measurement of transverse strains $\varepsilon_{\mathrm{p}}$ and longitudinal $\varepsilon_{\mathrm{w}}$, their functions were determined depending on the stress or (the sign of transverse deformation was changed to the opposite one) (Fig. 4b):

$$
\begin{aligned}
& \varepsilon_{p}=a_{p} \sigma_{r}+b_{p} \\
& \varepsilon_{w}=a_{w} \sigma_{r}+b_{w}
\end{aligned}
$$

where:

$\sigma_{r}$ - normal stresses, $a_{p}, a_{w}$ - directional coefficients, $b_{p}, b_{w}$ - constant terms.

By substituting relations (2) and (3) to formula (1), disregarding free words, which value is zero, dividing the denominator and divisor by the stress $\sigma$, we get:

$$
v=\frac{a_{p} \sigma_{r}}{a_{w} \sigma_{r}}=\frac{a_{p}}{a_{w}}
$$

Poisson's ratio is the ratio of the directional coefficients of the linear transverse and longitudinal strain function depending on the stress.

\subsection{Test results}

Table 1 presents the average results of tests of mechanical properties of structural methacrylic adhesive Plexus MA300 and epoxy Epidian 53. The value of standard deviations is given in brackets. The graphs (Fig. 5) present examples of stress as a function of longitudinal strain for the tested materials. 
Tab. 1: Determined mechanical properties of the tested adhesives.

\begin{tabular}{cccc}
\hline Mechanical properties & $\mathrm{MPa}$ & $\begin{array}{c}\text { Methacrylic adhesive } \\
\text { Plexus MA300 }\end{array}$ & $\begin{array}{c}\text { Epoxy adhesive } \\
\text { Epidian 53+Z1 }\end{array}$ \\
\hline $\begin{array}{c}\text { Tensile strength, Rm } \\
\text { Yield strength, Re }\end{array}$ & $\mathrm{MPa}$ & $1610.5(52.9)$ & $47.1(0.5)$ \\
\hline Young's modulus, E & - & $0.4(0.02)$ & $2730.6(74.7)$ \\
\hline Poisson ratio, $v$ & & & $0.39(0.03)$ \\
\hline
\end{tabular}

a)

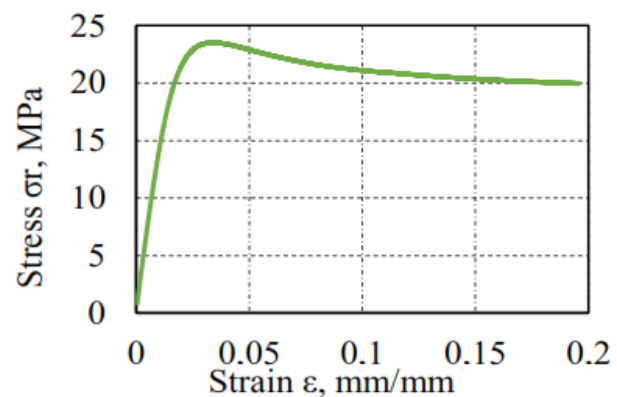

b)

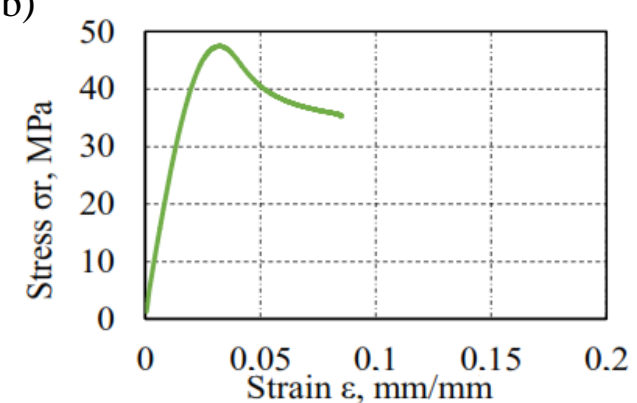

Fig. 5: Stress diagram as a function of strain: a) Plexus MA300 methacrylic adhesive; b) Epidian $53+Z 1$ epoxy adhesive.

\section{Conclusions}

The method of manufacturing specimens used in the presented studies allows to obtain reproducible results of mechanical properties of tested structural adhesives significantly differing in their viscosity. This is indicated by the small spread of results in the form of a low value of the determined standard deviation. The influence of the first cycle on the determined values of mechanical properties in the second cycle was not observed. The conducted research confirms the possibility of using the presented methods, using transverse extensometer in first load cycle and longitudinal extensometer in the second load cycle, to determine the Poisson ratio of structural adhesives.

\section{References}

Adams, R.D. and Wake, W.C. (1984) Structural Adhesive Joints in Engineering, Elsevier, London.

Maćkowiak, P. and Ligaj, B. (2016) Metody wyznaczania krzywych naprężenie - odkształcenie tworzyw adhezyjnych, Postępy w Inżynierii Mechanicznej, nr 8(4), pp. 53-61.

Maćkowiak, P. and Ligaj, B. (2017a) Metody badania właściwości mechanicznych kleju metakrylowego stosowanego w budowie pojazdów, Autobusy: technika, eksploatacja, systemy transportowe, nr 12(214), pp. 1092-1097.

Maćkowiak, P. and Ligaj, B. (2017b) Damage to adhesive single lap joint made of materials with different properties under static loading conditions, Engineering Mechanics 2017, Brno University of Technology, Brno, pp. 598-601.

Soltysiak, R., Boroński, D., Kotyk M. (2016) Experimental Verification of the Crack Opening Displacement Using Finite Element Method for CT Specimens Made of Ti6Al4V Titanium Alloy, AIP Conference Proceedings, vol 1780.

da Silva, L.F.M., Dillard, D.A., Blackman, B., Adams, R.D. (2012) Testing Adhesive Joints. John Wiley \& Sons.

da Silva, L.F.M., Adams, R.D. (2005) Measurement of the mechanical properties of structural adhesives in tension and shear over a wide range $\mathrm{nr}$ 19(2), pp.109-141.

PN-EN ISO 527-2:2012 - Plastics - Determination of tensile properties.

Wirwicki, M., ; Andryszczyk, M., Andrzejewska, A., Topolinski, T. (2017) Testing the strength of the adhesive connection in specimen - monotonic tensile and shear with under variable load, Engineering Mechanics 2017, Brno University of Technology, Brno, pp. 1054-1057. 